\title{
Impact of Social Support on Quality of Life among AIDS Patients in Kashmir Province of Jammu and Kashmir, India
}

Mohammad Amin Wani* and Sankar R

Department of Psychology, Annamalai University, Tamil Nadu, India

\begin{abstract}
Since 1981, AIDS remains one of the alarming issues in public health. It kills more than 39 million people globally. In this silent killer disease, patients not only suffer physiologically and economically but psychologically too. Their psychological well-being, mental health and quality of life also affected. The cardinal objective behind the present research was to investigate the effect of social support on quality of life of AIDS patients. Further, the study strived to find the level of social support and quality of life among male and female; married and unmarried AIDS patients. This study consisted sample of 60 AIDS patients with equal number of male and female patients selected through purposive sampling technique. Quality of Life was measured by Quality of Life Scale and for assessment of Social Support among patients Enriched Social Support Inventory was applied. For statistical analysis Mean, t-Test, Pearson Correlation and One Way ANOVA was applied by using SPSS 16.0 version. The findings show that male and married AIDS patients have a better level of quality of life than female and unmarried AIDS patients; they also receive more social support than female and unmarried patients. The results also revealed that two demographical variables gender and marital status are negatively significant correlated with Social Support and Quality of Life. Concurrently Social Support was found positively significant correlated with quality of life. On the basis of the findings in the present study we may conclude that gender, marital status as well as Social support are influential variables in quality of life. All these three variables have their impact on quality of life.
\end{abstract}

Keywords: Social support; Quality of life; HIV/AIDS; Gender; Marital status

\section{Introduction}

People in almost all the countries are threatened by an infectious disease called HIV/AIDS. Acquired Immune Deficiency Syndrome (AIDS), a viral disease caused by Human Immunodeficiency Virus (HIV), previously known as human T-cell lymphotropic virus 3 (HTLV-III) or lymphadenopathy associated virus (LAV) found in the infected person's body fluids via saliva, tears, blood, breast milk, semen, vaginal fluids, cerebrospinal fluid, plasma and biopsy specimens from brain and rectum. However the level of this virus in each of these fluids varies, HIV levels are very high in breast milk, blood and semen, moderate in anal and vaginal fluids (but higher during menstrual periods); simultaneously HIV is low in level in tears, saliva and urine. Human Immunodeficiency Virus is transmitted from an infected person through unprotected oral, vaginal as well as anal sex, infected blood transmission, sharing infected needles and from mother to child through breast feeding. HIV attacks the white blood cells of the immune system known as CD4 or T-helper cells, result minimizing the functions of CD4 cells, by this immune system became weak and the body fails to fight against infection. If CD4 cells drops below 200 cells/ $\mu \mathrm{l}$ HIV status will change from HIV positive to AIDS. AIDS does not cause death of the person immediately. But it has created a sense of fear in the minds of the people that is might cause sense of shame and social boycott which they consider worse than silent death. AIDS does not directly kill the person but failure of immune system causes various illness like Pneumocytsis Carinial Pneumonia (PCP), Kaposi's sarcoma (KS) and Cytomegalovirus (CMV), which are sufficient to kill the patient [1].

Considering 1981 when AIDS was firstly clinical reorganized in USA, 39.8 million people were infected by this disease. In 2015 it was found that 36.7 million people are living with AIDS among them 34.9 million are adults, 17.8 million are women and 1.8 million are children below the age group of 15years [2]. While as in India since 1986 when the first case of HIV was diagnosed by Solmon in Chennai city in Tamil Nadu State, 26.49 lakhs are diagnosed by this disease. However national AIDS control organization (NACO) report 2015 shows that 21.17 lakhs people in India are living with HIV/AIDS [3].

Quality of life is characterized as an individual's acumen to his position in life with regards to the way of life and esteem frameworks in which he live and in connection to their objectives, wishes, desires measures and concerns. The concept of quality of life was introduced in 1980 in order to measure the impact of health related problems on individual's everyday life. It considers individuals fulfillment and satisfaction towards every aspect of life. The term quality of life is popularly used to convey an overall sense of well-being. It is not only defined as one's general health, but it is used as an umbrella term that covers individual's psychological well-being, positive relationships, functional roles as well as subjective sense of life satisfaction. It is a multidimensional concept and its definition and assessment remains controversial [4]. In present days quality of life has been considered an important aspect in the field of research in people living with HIV/ AIDS.

Social consequences of HIV/ AIDS such as fear of social stigma, isolation and discrimination have negative impact on quality of life. People living with HIV/AIDS experience various physiological,

*Corresponding author: Mohammad Amin Wani, Ph.D Research scholar in Psychology Annamalai University, Tamil Nadu, India; Tel: +91 9103133348; E-mail: wanipsychology@gmail.com

Received August 16, 2017; Accepted September 13, 2017; Published September 20, 2017

Citation: Wani MA, Sankar R (2017) Impact of Social Support on Quality of Life among AIDS Patients in Kashmir Province of Jammu and Kashmir, India. J AIDS Clin Res 8: 729. doi: 10.4172/2155-6113.1000729

Copyright: (C) 2017 Wani MA, et al. This is an open-access article distributed unde the terms of the Creative Commons Attribution License, which permits unrestricted use, distribution, and reproduction in any medium, provided the original author and source are credited. 
psychological, sociological, as well as economical problems which specifically influences their quality of life. Physical, psychological, social as well as environmental domains of health-related quality of life are affected by individual's expectations, ideas, thoughts, experiences, beliefs, as well as their perceptions [5]. Nowadays, it is found by Kemppainen [6], Hough et al. [7] and Nunes et al. [8] that besides the medical therapy like ART, various psychological factors like social support can be effective and fruitful in the treatment process of HIV/ AIDS.

Social support is a critical issue to AIDS patients. Because of stigma inclined to AIDS patients often feel a sense of isolation, separation or detachment. In addition those who decide to discontinue sexual activity to abstain infecting their partners may lose an important part of their social support emotionally supportive system. Social support is significantly related with quality of life [8]. It enhances the life satisfaction and quality of life of people living with AIDS. Social support is altogether significantly linked with overall quality of life. Poor social support is one of the significant factors related with psychological problems in HIV/AIDS [9]. On the other hand proper social support has positive impact on mental health of people living with HIV/AIDS [10]. Patients supported by family and society experienced less distress and better health status than those received less social support [11]. Social support decreases signs and symptoms of disease and increase the quality of life of HIV patients [7]. Increasing social support increases the quality of life of HIV/AIDS persons [12]. Social support is significant predictor of quality of life [13]. It is significantly associated with better quality of life, minimizes the depressive symptoms among HIV/AIDS patients [14]. Such people can be supported by giving the information and education about how HIV spread from one person to another, what remedial measures should take by the infected partner during intercourse, or feeding the baby. Researcher also found that social support is a critical factor in HIV/ AIDS and plays a vital role in the treatment HIV/AIDS as well as in the quality of life. Social support impacts patients health related quality of life [15], is significantly associated with lower levels of depression [16], has positive effect on quality of life in people living with AIDS [17], positively related to health related quality of life. McCrough [18] highlighted that social support directly affects individual's physical, mental, as well as emotional wellbeing; it is positively correlated with psychological wellbeing of AIDS patients [11], also quality of life is affected by satisfaction with social support and coping style [19]. Tesfay et al. found significant gender difference in health related quality of life among people living with [5]. Rajeev et al. also reported significant difference in quality of life among those HIV/AIDS patients who was on ART and not on ART in some domains [20]. Nirmal et al. found female HIV patients have lower scores of quality of life than male patients; also quality of life scores were considerably lower among patients with less CD4 [21]. Bunjoungmanee et al. found moderate level of quality of life among HIV/AIDS patients; they also found that patients on ART treatment with good compliance have higher health related quality of life [22].

While reviewing the above literature, the researcher selected the problem to investigate the impact of social support on quality of life of AIDS patients, with following, objectives and hypotheses.

\section{Objectives}

- To find the level of social support and quality of life among male and female AIDS patients in Kashmir valley.

- To find the level of social support and quality of life among married and unmarried AIDS patients in Kashmir valley.
- To find out the correlation between gender, social support and quality of life in AIDS patients.

- To find out the correlation between marital status, social support and quality of life in AIDS patients.

\section{Hypotheses}

- $\quad \mathbf{H}_{\mathbf{1}}$ : There will be significant effect of social support on quality of life of male and female AIDS patients.

- $\mathbf{H}_{2}$ : There will be significant effect of social support on quality of life of married and unmarried AIDS patients.

- $\mathbf{H}_{3}:$ Female AIDS patients will show high level of social support and quality of life than male AIDS patients.

- $\mathbf{H}_{4}$ : Married AIDS patients will show high level of social support and quality of life than unmarried AIDS patients.

- $\mathbf{H}_{5}$ : Gender will be significantly correlated with social support and quality of life.

- H $_{6}$ : Marital status will be significantly correlated with social support and quality of life.

\section{Variables}

In the present study experimental variable is, social support, criterion variable is quality of life and demographical variables are gender and marital status.

\section{Sample}

The present study was conducted on a sample of 60 AIDS patients equally divided into two groups on the basis of gender (males and females). Further these two groups were equally subdivided into two more groups on the basis of marital status (married and unmarried), selected through simple random sampling technique. Only those AIDS patients were selected in this study who met following inclusion and exclusion criteria.

\section{Inclusion criteria}

- Patients hail from Srinagar, Baramulla and Budgam districts

- Patients between the age group of 20-40 years old

- Both Male and Female patients were included

- Patients registered in ART center Srinagar from last 4 years

\section{Exclusion criteria}

- CD4 Count was excluded

- Education level of the patient was not taken

- History of previous psychological as well as physiological illness

- Family pattern of patients were excluded

\section{Psychological tools}

1. Quality of life scale

2. Enriched Social Support Inventory

Quality of life scale: Quality of life Scale constructed and standardized by Sarika Sharama and Nakhat Nasreen was used to measure the level of quality of life of patients. The scale consisted of 42 
items (34 positive and 8 negative items) with three point scale (Always, Seldom and Never). Positive items were scored as 3, 2 and 1, while as negative items were scored as 1,2 and 3 , respectively. Cronbach's a (alpha) method was used to determine the reliability of the test which was found 0.806 . And validity was measures through face and construct types of validity.

Enriched social support inventory: Seven items Enriched Social Support Inventory was applied to find the level of social support among Patients. Out of 7 items first 6 items were scored as 1 (None of the time), 2 (A little of the time), 3 (Some of the time), 4 (Most of the time) and 5 (All the time), while as item 7 was scored as 4 for Yes or 2 for No response respectively. Reliability of the scale was found through intra class correlation coefficient and Cronbach's Alpha methods and was found 0.94 and 0.88 , respectively.

\section{Procedure}

The study was conducted in Kashmir province of Jammu and Kashmir State consisted sample of 60 AIDS patients, selected through purposive sampling technique from SKIMS, ART center Srinagar. Prior to administrating the Quality of life Scale and Social Support Scale on patients, the researcher got permission from concerned authority. Information about the patients was also received from the doctor in charge at ART centre. While meeting each patient individually proper rapport was established and they were told the purpose of meeting. After that Quality of life Scale and Social Support Scale was administrated on them. During examination the researcher helped those patients who had difficulty in understanding the statements, after 15-25 min the patient handed over the questionnaire to the researcher and were thanked for their cooperation. Therefore the data was collected from AIDS patients, after that obtained data was arranged in tabular form and then systematically analyzed by applying Mean, t-test, ANOVA and Pearson Correlation using SPSS 16.0 version.

\section{Results}

The main findings of the present study are shown in tables given underneath (Tables 1-5).

\begin{tabular}{|l|c|c|c|c|c|}
\hline Variables & & Sum of Squares & df & Mean Square & F \\
\hline \multirow{2}{*}{$\begin{array}{l}\text { Social } \\
\text { Support }\end{array}$} & Between Groups & 150.41 & 1 & 150.41 & \multirow{2}{*}{$8.70^{* *}$} \\
\cline { 2 - 5 } & Within Groups & 1002.43 & 58 & 17.28 & \\
\cline { 2 - 5 } & Total & 1152.84 & 59 & & \\
\hline $\begin{array}{l}\text { Quality of } \\
\text { Life }\end{array}$ & Between Groups & 1363.26 & 1 & 1363.27 & \multirow{2}{*}{$4.37^{*}$} \\
\cline { 2 - 5 } & Within Groups & 18073.33 & 58 & 311.61 & \\
\cline { 2 - 5 } & Total & 19436.59 & 59 & & \\
\hline
\end{tabular}

**=Significant at the 0.01 level, ${ }^{*}=$ Significant at the 0.05 level

Table 1: ANOVA summary of social support and quality of life of male and female AIDS patients.

\begin{tabular}{|l|c|c|c|c|c|}
\hline Variables & & $\begin{array}{c}\text { Sum of } \\
\text { Squares }\end{array}$ & df & $\begin{array}{c}\text { Mean } \\
\text { Square }\end{array}$ & F \\
\hline \multirow{3}{*}{ Social Support } & Between Groups & 421.35 & 1 & 421.35 & \multirow{2}{*}{$33.40^{\star *}$} \\
\cline { 2 - 5 } & Within Groups & 731.50 & 58 & 12.61 & \\
\cline { 2 - 5 } & Total & 1152.84 & 59 & & \\
\hline \multirow{2}{*}{ Quality of Life } & Between Groups & 821.40 & 1 & 821.40 & \multirow{2}{*}{2.56 N.S } \\
\cline { 2 - 6 } & Within Groups & 18615.20 & 58 & 320.95 & \\
\cline { 2 - 5 } & Total & 19436.60 & 59 & & \\
\hline
\end{tabular}

*=Significant at the 0.01 level, N.S=Significant at the 0.05 level

Table 2: ANOVA summary of social support and quality of life of married and unmarried AIDS patients.

\begin{tabular}{|c|c|c|c|c|c|c|c|}
\hline Variables & Gender & No & Mean & S.D & S.E.M & df & t-value \\
\hline \multirow{2}{*}{$\begin{array}{l}\text { Social } \\
\text { Support }\end{array}$} & Male & 30 & 19.63 & 4.16 & 3.70 & \multirow[b]{2}{*}{58} & \multirow[b]{2}{*}{$2.95^{\star *}$} \\
\hline & Female & 30 & 16.46 & 4.15 & 2.65 & & \\
\hline \multirow[t]{2}{*}{ Quality of Life } & Male & 30 & 78.06 & 20.27 & 0.76 & \multirow[b]{2}{*}{58} & \multirow[b]{2}{*}{$2.09^{*}$} \\
\hline & Female & 30 & 68.53 & 14.56 & 0.75 & & \\
\hline \multirow{2}{*}{$\begin{array}{l}\text { Social } \\
\text { Support }\end{array}$} & Married & 30 & 20.70 & 4.17 & 0.76 & \multirow[b]{2}{*}{58} & \multirow[b]{2}{*}{$5.78^{\star \star}$} \\
\hline & Unmarried & 30 & 15.40 & 2.79 & 0.51 & & \\
\hline \multirow[t]{2}{*}{ Quality of Life } & Married & 30 & 77.00 & 19.15 & 3.49 & \multirow[b]{2}{*}{58} & \multirow[b]{2}{*}{1.60 N.S } \\
\hline & Unmarried & 30 & 69.60 & 16.58 & 3.02 & & \\
\hline
\end{tabular}

${ }^{* *}=$ Significant at the 0.01 level, ${ }^{*}=$ Significant at the 0.05 level, N.S=Significant at the 0.05 level

Table 3: Gender and marital status wise mean, S.D, SED and t-value of social support and quality of life scores of AIDS patients.

\begin{tabular}{|l|c|c|c|}
\hline & Gender & Social Support & Quality of Life \\
\hline Gender & 1 & $-0.361^{* *}$ & $-0.265^{*}$ \\
\hline Social Support & $-0.361^{* *}$ & 1 & $0.424^{\star *}$ \\
\hline Quality of Life & $-0.265^{*}$ & $0.424^{* *}$ & 1 \\
\hline
\end{tabular}

** Correlation is significant at the 0.01 level (2-tailed), ${ }^{*}$ Correlation is significant a the 0.05 level (2-tailed)

Table 4: Correlation between gender, social support and quality of life.

\begin{tabular}{|l|c|c|c|}
\hline & Marital Status & Social Support & Quality of Life \\
\hline Marital Status & 1 & $-0.605^{* *}$ & -0.206 \\
\hline Social Support & $-0.605^{* *}$ & 1 & $0.424^{* *}$ \\
\hline Quality of Life & -0.206 & $0.424^{* *}$ & 1 \\
\hline
\end{tabular}

** Correlation is significant at the 0.01 level (2-tailed)

Table 5: Correlation between marital status, social support and quality of life.

\section{Discussion}

The findings of present study validated that social support have significant effect on quality of life of male and female AIDS patients. The obtained $\mathrm{f}$-value $(\mathrm{F}=8.70,(\mathrm{df}=1,58), \mathrm{P}<0.01)$ of social support is found significant. Simultaneously the obtained f-ratio $(\mathrm{F}=4.37,(\mathrm{df}=1,58)$, $\mathrm{P}<0.05$ ) of quality of life of the same group was also found more than tabulation value at 0.05 level. Therefore social support is an influential variable in quality of life of AIDS patients, and the first hypothesis is accepted. Similar findings are reported by Pereira and Canavarro [23], they found significant gender differences in quality of life among HIV infected patients, Shin [15], also affirmed that positive function of social support influences the health related quality of life among HIV/ AIDS patients. Simultaneously Friedland et al. [17] reported that social support positively affects the quality of life among people living with AIDS (PLWHA).

The findings also show significant effect of social support on quality of life of married and unmarried AIDS patients. As the obtained f-value $(\mathrm{F}=33.40,(\mathrm{df}=1,58), \mathrm{P}<0.01)$ of social support exceeds higher than the tabulation value at 0.01 level. Therefore social support is representative variable. But the f-value $(\mathrm{F}=2.56,(\mathrm{df}=1,58), \mathrm{P}>0.05)$ of quality of life scores is found insignificant at 0.05 level which rejected the second hypothesis.

The results of present study also demonstrated that there is significant difference between the mean scores of male and female AIDS patients in respect to their social support and quality of life. The Mean, S.D and SEM of social support scores of male and females AIDS patients was found (Male $(M=19.63$, S.D=4.16, SEM=3.70), (Female $\mathrm{M}=16.46, \mathrm{~S} . \mathrm{D}=4.15, \mathrm{SEM}=2.65))$ and $\mathrm{t}$-value $(\mathrm{t}=2.95,(\mathrm{df}=58), \mathrm{P}<0.01)$. Similarly the Mean, S.D and SEM of quality of life scores of male 
and females AIDS patients was found (Male $(M=78.06, S . D=20.27$, $\mathrm{SEM}=0.76$ ), (Female $\mathrm{M}=68.53$, S.D=14.56, $\mathrm{SEM}=0.75)$ ) and $\mathrm{t}$-value $(\mathrm{t}=2.09,(\mathrm{df}=58), \mathrm{P}<0.05)$. Thus male AIDS patients have higher levels of social support and quality of life scores than female patients. Therefore third hypothesis is accepted. Tesfay et al. [5] also found significant gender differences in health related quality of life among people living with HIV/AIDS, it is also reported that female patients had low score in all health related quality of life domains than male patients. Rajeev et al. [20] also found significant mean difference in quality of life scores among HIV/AIDS patients, simultaneously Chandra et al. [24], Casado [25] and Kohli et al. [26] confirmed that women have significantly lower quality of life scores as compared to men.

On the basis of our findings it can be deduced that married AIDS patients have high level of social support and quality of life than unmarried AIDS patients. Because the mean value of married patients in both social support and quality of life is higher than mean value of unmarried patients in both social support and quality of life. The obtained Mean, S.D, SEM and t-value of married and unmarried patients in respect to social support was found (Married $(M=20.70$, $\mathrm{S} . \mathrm{D}=4.17, \mathrm{SEM}=0.76)$, (Unmarried $\mathrm{M}=15.40, \mathrm{~S} . \mathrm{D}=2.79, \mathrm{SEM}=0.51)$ and $(\mathrm{t}$-value $=5.78,(\mathrm{df}=58), \mathrm{P}<0.01)$ which is more than critic value given in the table at 0.01 level of significance. Concurrently the obtained $t$-value $(\mathrm{t}$-value $=1.60, \mathrm{df}=58), \mathrm{P}<0.05)$ of quality of life scores of married and unmarried AIDS patients was found less than tabulation value at 0.05 level of significance, which rejects the fourth hypothesis. The obtained Mean, S.D and SEM of quality of life of same group was found (Married $(\mathrm{M}=77.00, \mathrm{~S} . \mathrm{D}=19.15, \mathrm{SEM}=3.49)$, (Unmarried $\mathrm{M}=69.60$, S. $\mathrm{D}=16.58$, SEM=3.02), respectively.

Findings also shows negative significant correlation of gender with social support $(-0.361)$ and quality of life $(-0.265)$. Both the obtained values were found significant at 0.01 and 0.05 level. Positive correlation is found between social support and quality of life (0.424) significant at 0.01 levels. Therefore gender is negatively significantly correlated with social support and quality of life, while as social support positively correlated with quality of life. Therefore fifth hypothesis is also accepted.

The results also show that marital status is negatively significantly correlated with social support $(-0.605)$ and quality of life $(-0.206)$. Simultaneously social support is found positively correlated with quality of life (0.424), all these obtained values are found higher than table value at 0.01 level of significance. Therefore the last hypothesis is also accepted. Lan et al. [27], Yadav [28] and Nunes et al. [8] also found the significant relationship between social support and quality of life among people living with HIV/AIDS.

\section{Conclusion}

In the light of the above observations, it can be concluded that social support, gender and marital status are influential variables in quality of life of AIDS patients. People living with HIV/AIDS have physical, psychological as well as social problems. Most of AIDS patients are isolated from their families, workplaces even societies. They have stress, anxieties, depressions, even suicidal thoughts and ideations, they feel lonely and avoided by dear ones. Thus as a human being it is our moral responsibility that these people should be supported throughout life. Social support not only reduces stress level and depression level but it also improves physical, psychological, social as well as spiritual health. People living with AIDS can be support financially, or by giving material goods for their daily use. Education and material is not enough for those people who are living with AIDS. But there should be an emotionally support too, they need love, care, affection, trust, encouragement. That is how they can live normal life; people will not let them alone, they make social relationship with them, these people lived with various psychological problems results breaking of social relationship. Thus it is our moral responsibility to stand with them when they need us; social support plays a vital role in one's life and has impact on individual's quality of life.

\section{Acknowledgement}

Researchers undertake marvelous opportunity to acknowledge their deepest sense of gratitude to all those AIDS patients who cooperate during data collection. It is proud and eternal privilege for us to record our cordial and sincere gratitude and indebtedness to Doctor and Counselor In charge ART Center SKIMS Srinagar.

\section{References}

1. Bennett $P$ (2011) Abnormal and clinical psychology: An introductory text book (3rd Edn) McGraw Open University Press Two Penn Plaza, New York, USA.

2. http://www.who.int/hiv/en/

3. NACO (2015) Indian HIV Estimations 2015 technical report. National AIDS Control Organization, National Institute of Medical Statistics, ICMR Ministry of Health \& Family Welfare Government of India.

4. Jahan F, Husain A (2015) Quality of life among HIVIAIDS seroconcordant and serodiscordant spouses. Int J Indian Psychol 3: 49-55.

5. Tesfay A, Gebremariam A, Gerbaba M, Abrha H (2015) Gender differences in health related quality of life among people living with HIV on highly active antiretroviral therapy in Mekelle Town, Northern Ethiopia. Bio Med Res Int 2015: 1-9.

6. Kemppainen JK (2001) Predictors of quality of life in AIDS patients. J Assoc Nurses AIDS Care 12: 61-70.

7. Hough ES, Magnan MA, Templin T, Gadelrab HF (2005) Social network structure and social support in HIV positive inner city mothers. J Assoc Nurses AIDS Care 16: 14-24.

8. Nunes JA, Raymond SJ, Nicholas PT, Webster A (1995) Social support, quality of life, immune function and health in persons living with HIV. J Holist Nurs 13 174-198.

9. Adewuya AO, Afolabi MO, Ola BA, Ogundele OA, Ajibare AO, et al. (2007) Psychiatric disorders among the HIV positive population in Nigeria: A control study. J Psychosom Res 63: 203-206.

10. Nakimuli ME, Musisi S, Katabira E, Nachega J, Bass J (2011) Prevalence and factors associated with depressive disorders in an HIV+ rural patient population in southern Uganda. J Affect Disord 135: 160-167.

11. Bajunirwe F, Tisch DJ, King CH, Arts EJ, Debanne SM, et al. (2009) Quality of life and social support among patients receiving antiretroviral therapy in Western Uganda. AIDS Care 21: 271-279.

12. Charkhian A, Fekrazad H, Sajadi H, Rahgozar M, Abdolbaghi M, et al. (2014) Relationship between health related quality of life and social support in HIV infected people in Tehran, Iran. Iran J Public Health 43: 100-106.

13. Khumsaen N, Aoup W, Thammachak $P$ (2012) Factors influencing quality of life among people living with HIV (PLWH) in Suphanburi Province, Thailand. J Assoc Nurses AIDS Care 23: 63-72.

14. Rotheram MJ, Stein JA, Jiraphongsa C, Khumtong S, Lee SJ, et al. (2010) Benefits of family and social relationships for Thai parents living with HIV. Prev Sci 11: 298-307.

15. Shin S (2011) A study on health related quality of life in people living with HIV/ AIDS in Korea. Health and Social Welfare Review 31: 424-453.

16. Debra AM, Barbara A (2000) Psychological distress among HIV positive adolescents in the reach study: Effects of life stress, social support and coping J Adolesc Health 27: 391-398.

17. Friedland J, Renwick R, McColl M (1996) Coping and social support as determinants of quality of life in HIVIAIDS. AIDS Care 8: 15-31.

18. McCrough (1990) Assessing social support of people with AIDS. Oncol Nurs Forum 17: 1-5

19. Swindells S, Mohr J, Justis JC, Berman S, Squier C, et al. (1999) Quality of life in patients with human immunodeficiency virus infection: Impact of socia support, coping style and hopelessness. Int J STD AIDS 10: 383-391. 
Citation: Wani MA, Sankar R (2017) Impact of Social Support on Quality of Life among AIDS Patients in Kashmir Province of Jammu and Kashmir, India. J AIDS Clin Res 8: 729. doi: 10.4172/2155-6113.1000729

20. Rajeev KH, Yuvaraj BY, Nagendra G, Ravi K (2012) Impact of HIV/AIDS on quality of life of people living with HIV/AIDS in Chitradurga district, Karnataka. Indian J Public Health 56: 116-121.

21. Nirmal B, Divya KR, Dorairaj VS, Venkateswaran K (2008) Quality of life in HIV/ AIDS patients: A cross sectional study in south India. Indian J Sex Transm Dis 29: $15-17$.

22. Bunjoungmanee $P$, Chunloy $K$, Tangsathapornpong A, Khawcharoenporn $T$, Apisarnthanarak A (2014) Quality of life assessment among patients living with HIVIAIDS at a tertiary care hospital in Thailand. Southeast Asian J Trop Med Public Health 45: 834-842.

23. Pereira M, Canavarro MC (2011) Gender and age differences in quality of life and the impact of psychopathological symptoms among HIV infected patients. AIDS Behav 15: 1857-1869.
24. Chandra PS, Satyanarayana VA, Satishchandra P, Satish KS, Kumar M (2009) Do men and women with HIV differ in their quality of life? A study from South India. AIDS Behav 13: 110-117.

25. Casado A (2005) Measurement of quality of life of HIV individuals: Perspectives and future directions. Indian J Med Res 122: 282-284.

26. Kohli RM, Sane S, Kumar K, Paranjape RS, Mehendale SM (2005) Assessment of quality of life among HIV infected persons in Pune, India. Indian J Med Res 122: $297-304$

27. Lan G, Yuan Z, Cook A, Xu Q, Jiang H, et al. (2015) The relationships among social support and quality of life in persons living with HIVIAIDS in Jiangxi and Zhejiang provinces, China. AIDS Care 27: 946-953.

28. Yadav S (2010) Perceived social support, hope and quality of life of persons living with HIVIAIDS: A case study from Nepal. Qual Life Res 19: 157-166. 